\title{
Kritik Sastra Feminis dalam Komik Kaichō wa Meido-Sama! Karya Hiro Fujiwara
}

\author{
Made Yani Anggarawati", Silvia Damayanti, Ni Made Andry Anita Dewi \\ Prodi Sastra Jepang, Fakultas Ilmu Budaya, Universitas Udayana \\ [yani.anggarawati@gmail.com] \\ *Corresponding Author
}

\begin{abstract}
The title of this research is "The Feminist Literary Criticism in Kaichō wa Meido-Sama! by Hiro Fujiwara". This research focuses on two problems: how the feminism is shown in Kaichō wa Meido-Sama! by Hiro Fujiwara and how is the main character's feminism ideology influence another character in the comic. Methods used in this research is descriptive analysis method and the informal method. The theories used are feminism theory by Lorber (1997) and semiotics by Danesi (2011). The analysis result shows that feminisms ideology that revealed in the comics is liberal feminism, such as women also can be physically strong, rational and using men's language; women as a leader; women were not inferior; and social discrimination against women. Liberal feminism ideology of the main character has positive and negative influences to another character in the comic. The positive influences show on some attitudes from characters such as Shotaro Kano and Tora Igarashi towards women and also female and male students relation. The negative influence shows in the dependence female students on the female character, Misaki Ayuzawa.
\end{abstract}

Keywords: liberal feminism, shōjo manga, gender

\begin{abstract}
Abstrak
Penelitian ini berjudul "Kritik Sastra Feminis dalam Komik Kaichō wa Meido-Sama! Karya Hiro Fujiwara". Penelitian ini bertujuan untuk mengetahui unsur feminisme yang ditujukan tokoh Misaki serta pengaruhnya terhadap tokoh lain dalam komik Kaichō wa Meido Sama! karya Hiro Fujiwara. Metode yang digunakan dalam penelitian ini adalah metode deskriptif analisis. Teori yang digunakan adalah teori feminisme yang dikemukakan oleh Lorber (1997), dan teori semiotika oleh Danesi (2011). Berdasarkan hasil penelitian, didapatkan feminisme yang dominan ditunjukkan dalam komik adalah feminisme liberal, yaitu antara lain: (1) citra perempuan yang kuat, rasional dan menggunakan bahasa laki-laki; (2) perempuan sebagai pemimpin; (3) perempuan yang tidak inferior; serta (4) menunjukkan sistem masyarakat yang masih mendiskriminasi perempuan berupa marginalisasi dan stereotif negatif. Selanjutnya, pengaruh feminisme liberal yang ditunjukkan Misaki terhadap tokoh lain berupa pengaruh positif dapat dilihat pada perubahan sikap tokoh Kano Shotaro dan Igarashi Tora, serta perubahan relasi antara perempuan dan laki-laki. Selain itu, pengaruh negatif ditunjukkan pada ketergantungan siswi perempuan terhadap pertolongan tokoh Misaki.
\end{abstract}

Kata kunci: feminisme liberal, shōjo manga, gender

PENDAHULUAN

Selama berabad-abad, perempuan senantiasa terikat dalam ketimpangan gender yang kerap tercermin pada karya- karya sastra. Meskipun merupakan wadah bagi kesenjangan gender, karya sastra juga dapat menjadi wahana dalam meningkatkan kesadaran perempuan

\begin{tabular}{lll}
\hline Info Article & & \\
\hline Received & $:$ & $28^{\text {th }}$ August 2020 \\
Accepted & $:$ & $18^{\text {th }}$ February 2020 \\
Publised & $:$ & $29^{\text {th }}$ February 2020
\end{tabular}


mengenai kesenjangan gender itu sendiri (Sugihastuti dan Suharto, 2010:34). Seiring dengan perkembangan kesadaran mengenai kesenjangan gender di tengah masyarakat, munculah Kritik Sastra Feminis sebagai jembatan yang menghubungkan antara feminis dan karya sastra. Salah satu jenis karya yang menarik untuk diteliti secara feminis adalah shōjo manga.

Shōjo manga adalah jenis komik yang berasal dari Jepang yang ditujukan untuk anak atau remaja perempuan. Hal ini membuat shōjo manga turut menjadi wahana penyadaran gender yang mempengaruhi pola pikir perempuan Jepang. Tokoh perempuan pada shōjo manga pada umumnya dipenuhi dengan berbagai stereotip seperti lemah, submisif, dan bergantung pada laki-laki. Dibalik kentalnya stereotip tersebut, tercipta sebuah komik bergenre shojo manga dengan tokoh utama perempuan yang mandiri dan berjuang keras untuk menjadi unggul melawan subordinasi laki-laki yang sesuai dengan pandangan feminisme yang berjudul Kaichō wa Meido-sama! Karya Hiro Fujiwara.

Penelitian mengenai perempuan sebelumnya pernah dilakukan oleh Damayanti (2018) dengan judul "Puisi Cinta Shuntaro Tanikawa dan W.S. Rendra: sebuah Kajian Sastra Bandingan". Penelitian Damayanti memberikan gambaran mengenai citra perempuan dalam karya sastra. Selain itu, penelitian ini juga menggunakan penelitian berjudul "Pengaruh Pola Asuh Ibu Terhadap Perkembangan Kepribadian Tokoh Hikaru Narumi dan Hiro Narumi dalam Manga Piece Karya Ashihara Hinako" oleh Sisilia, dkk (2016). Penelitian Sisilia memberikan gambaran mengenai pola asuh ibu yang berkaitan juga dengan peran gender yang ditanamkan pada anak. Penelitian menganalisis unsur feminisme liberal yang ditunjukkan komik dengan menggunakan teori Feminisme oleh
Lorber (1997) dan Teori Semiotika Danesi (2011).

Berdasarkan uraian diatas, pokok masalah yang dibahas adalah: Bagaimanakah unsur feminisme yang ditunjukkan dalam komik Kaichō wa Meido Sama! karya Hiro Fujiwara?, serta Bagaimanakah pengaruh feminisme liberal tokoh Misaki terhadap tokoh lain dalam komik Kaichō wa Meido Sama! karya Hiro Fujiwara?

Penelitian ini bertujuan untuk menambah wawasan mengenai kritik sastra feminis, serta menambah penelitian berperspektif feminis untuk meningkatkan kesadaran gender di tengah masyarakat. Secara khusus, penelitian ini bertujuan untuk mengetahui unsur feminisme dalam komik Kaichō wa Meido Sama! karya Hiro Fujiwara dan pengaruh feminisme tokoh Misaki terhadap tokoh lainnya.

\section{METODE}

Prosedur pengumpulan data dalam penelitian ini dilakukan dengan metode studi kepustakaan. Analisis feminisme dilakukan dengan teori Feminisme Liberal oleh Lorber (1997) dan teori Semiotik oleh Danesi (2011), serta disajikan dalam bentuk informal. Sumber data dari penelitian ini adalah komik Kaichō wa Meido-Sama! karya Fujiwara yaitu volume satu (2006), dua (2007a) tiga (2007b) dan 18 (2013). Komik ini merupakan shōjo manga yang diterbitkan oleh perusahaaan penerbitan Hakusensha.

\section{HASIL DAN PEMBAHASAN}

Kaicho wa Meido-Sama! adalah sebuah komik yang menceritakan kehidupan seorang siswi SMA bernama Misaki Ayuzawa. Misaki dengan semangat dan usaha yang keras berhasil memperoleh peringkat terbaik serta jabatan sebagai ketua OSIS di SMA yang sebagian besar siswanya adalah laki-laki. Meskipun merupakan shōjo manga, Kaichō-wa Meido-Sama! menunjukkan 
independensi, kekuatan dan kepemimpinan perempuan yang berbeda dengan shōjo manga pada umumnya. Berikut pembahasan mengenai membahas dalam komik Kaichō wa Meido-Sama! karya Hiro Fujiwara dan pengaruh feminisme tokoh Misaki terhadap tokoh lainnya. Adapun hasil penelitian tersebut dijabarkan sebagai berikut.

\section{Feminisme dalam komik Kaichō wa Meido-Sama! karya Hiro Fujiwara}

Unsur feminisme yang dominan ditunjukkan dalam komik Kaichō wa Meido-Sama! karya Hiro Fujiwara adalah feminisme liberal. Feminisme liberal yang ditunjukkan dalam komik adalah feminisme yang menjunjung tinggi kesetaraan gender. Gender merupakan konstruksi sosial dan bukan berasal dari biologis, sehingga perempuan dan lakilaki sesungguhnya tidak memiliki perbedaan yang signifikan. Komik Kaichō wa Meido-Sama! menggambarkan kesetaraan antara perempuan dan laki-laki yang sejalan dengan pandangan feminisme liberal. Hal tersebut dapat dilihat dari citra perempuan yang kuat, rasional dan menggunakan bahasa laki-laki, posisi perempuan sebagai pemimpin, perempuan yang tidak inferior, serta diskriminasi terhadap perempuan berupa marginalisasi dan pelabelan negatif. Adapun feminisme liberal dalam komik Kaichō wa Meido Sama! dijabarkan sebagai berikut.

\section{a. Citra Perempuan}

Feminisme liberal menjunjung pemikiran perbedaan gender tidak berdasar pada biologis, serta perempuan dan laki-laki sesungguhnya tidak memiliki perbedaan yang begitu signifikan (Lorber, 1997:9). Perempuan sering kali dicitrakan lemah lembut, cantik, emosional atau keibuan; sementara laki-laki dianggap kuat, rasional, jantan dan perkasa (Fakih, 2013:8). Komik Kaichō wa Meido-Sama! menggambarkan Misaki sebagai tokoh utama perempuan yang kuat, rasional serta menggunakan bahasa laki-laki. Kekuatan fisik Misaki dapat dilihat pada gambar (1).

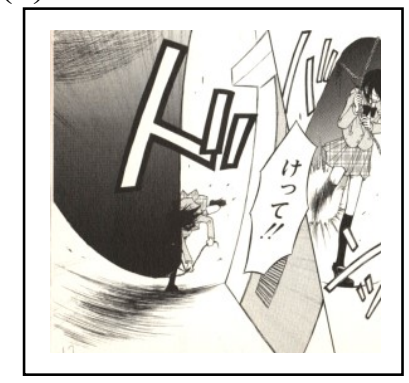

Gambar (1)

(Kaichō wa Meido-Sama!Vol 1, 2006:12)

Gambar (1) merupakan gambar yang menunjukkan Misaki yang memindahkan sandbag seberat $50 \mathrm{~kg}$ sendirian. Penggambaran tokoh Misaki yang menunjukkan perempuan yang kuat berbeda dengan stereotip perempuan di Jepang pada umumnya. Di Jepang, sifatsifat yang melekat pada laki-laki dan perempuan telah dibentuk selama berabad-abad dengan telah disesuaikan dengan ekspektasi sosial.

Beberapa program televisi anak misalnya Rupan III atau Ultraman memberikan penggambaran sifat perempuan yang cantik, memiliki mata besar, memiliki proporsi yang ideal serta glamor sebagai sosok pacar dari tokoh utama yang bertugas untuk merawat yang lemah (Inoue dalam Davies and Ikeno, 2002:181). Perempuan ditempatkan sebagai peran perawat yang lemah dan harus dilindungi oleh laki-laki. Dikarenakan sifat-sifat gender yang melekat pada diri seseorang khususnya perempuan sudah ditanamkan sejak kecil, sifat-sifat perempuan tersebut melekat pada diri perempuan menjadi sebuah identitas sosial. Sifat-sifat seperti cantik, lemah lembut, bijaksana, dan patuh merupakan ekspektasi masyarakat terhadap perempuan. Sifat lemah inilah yang ditentang oleh feminisme liberal. 
Penggambaran tokoh Misaki yang memiliki kekuatan fisik yang kuat sejalan dengan pandangan feminisme liberal yang menjunjung tinggi kesetaraan gender.

Citra perempuan yang sejalan dengan feminisme liberal juga dapat dilihat pada penggambaran perempuan yang rasional dan menggunakan bahasa laki-laki. Seseorang yang rasional cenderung akan memiliki kemampuan menalar dan tidak menggunakan emosi dalam menyelesaikan sesuatu (Chaplin, 2011:416). Hal ini ditunjukkan pada data (1).

$$
\begin{aligned}
\text { (1) 碓井 : 怒らないの? } \\
\text { 美咲 : } \cdots \text { なんで } \\
\text { 碓井 : 「碓井のせいで妹キャ } \\
\text { ラができなかった ! 」か } \\
\text { 美咲 : } \cdots \text { 別に、できなかったの } \\
\text { は私の実力不足が原因だ。演 } \\
\text { じることに背一杯になると、 } \\
\text { 冷静な判断できなくなって、 } \\
\text { ついムキになってしまうから } \\
\text { な… }
\end{aligned}
$$

(会長はメイド様!第3巻99 100ページ)

Usui : Okoranaino?

Misaki : ... Nande

Usui : "Usui no sei de imouto kyara ga dekinakatta!" toka

Misaki : ...Betsu ni, Dekinakatta no wa watashi no jitsuryoku busoku ga gen'in da. Enjiru koto ni sei

\begin{tabular}{|c|c|}
\hline sui & $\begin{array}{l}\text { "Gara-gara Usui aku tidak } \\
\text { bisa memerankan karakter } \\
\text { adik!" misalnya }\end{array}$ \\
\hline Misaki & $\begin{array}{llr}\ldots & \text { Aku } & \text { tidak } \\
\text { Aku } & \text { tidak } \\
\text { memerankannya }\end{array}$ \\
\hline & $\begin{array}{l}\text { memang kemampuanku } \\
\text { kurang. Aku terlalu serius } \\
\text { untuk memerankannya } \\
\text { sehingga aku jadi tidak bisa } \\
\text { berpikir jernih dan malah jadi } \\
\text { mudah tersinggung... }\end{array}$ \\
\hline
\end{tabular}
ippai ni naru to, reisei na handan dekinaku natte, tsui muki ni natte shimau kara na...

(Kaichō wa Meido-Sama! Vol 3, 2007:99-

Terjemahan:

Usui : Kau tidak marah?

Misaki : ... Kenapa?
Data (1) percakapan antara Usui dan Misaki. Usui menanyakan kepada Misaki apakah ia marah kepada Usui. Namun Misaki mengatakan bahwa ketidakmampuannya dalam memerankan karakter adik perempuan yang manis adalah karena kemampuannya sendiri yang kurang. Misaki tidak menghadapi kegagalannya secara emosional dengan menyalahkan Usui, namun mencari penyebab kekurangan pada dirinya sendiri. Cara pandang ini dinilai sebagai cara pandang menurut pikiran sehat dan menurut penalaran yang logis yang menunjukkan bahwa perempuan juga bisa mengambil keputusan secara rasional.

Data (1) juga menunjukkan citra tokoh Misaki yang menggunakan bahasa laki-laki berupa partikel akhir " $n a$ ". Maskulinitas atau feminimitas bukanlah sejak awal berada pada dalam diri manusia, namun kata-kata digunakan oleh manusia untuk mengekspresikan feminimitas dan maskulinitas sesuai dengan keinginannya (Nakamura, 2010:22). Tokoh Misaki menggunakan bahasa laki-laki untuk menunjukkan bahwa dirinya setara dengan laki-laki.

Menurut feminisme liberal, ekspektasi sosial akan sifat perempuan yang lemah, lembut dan harus dilindungi sebenarnya tidak berasal dari tubuh perempuan itu sendiri. Komik Kaichō wa Meido-Sama! menggambarkan perempuan yang kuat, rasional dan menggunakan bahasa laki-laki sesuai dengan pandangan feminisme liberal. 
b. Posisi Perempuan

Menurut feminisme liberal, perempuan harus mendapatkan kesempatan yang sama dengan laki-laki dalam profesi, pemerintahan dan institusi kebudayaan (Lorber, 1997:9). Komik Kaichō-wa Meido-Sama! karya Hiro Fujiwara menggambarkan tokoh Misaki sebagai perempuan yang kompeten sebagai seorang pemimpin. Hal ini dapat dilihat pada data (2).

（2）堂々とのさばる男共を前に力のな

い女性陣はただ耐えるのみ、そんな

もん我慢できるか! そうして状況を

打開すべく私は頑張つた、ひたすら

頑張つた、そうして教師達の信頼を

得、この便利な立場を手にしたのだ

(会長はメイド様! 第1巻6ページ)

Doudou to nosabaru otoko domo wo mae ni chikara no nai josei jin wa tada taeru nomi, sonna mon gaman dekiruka! Soushite joukyou wo dakai subeku watashi wa ganbatta, hitasura ganbatta, soushite kyoushitachi no shinrai wo e, kono benri na tachiba wo te ni shita noda

(Kaichō wa Meido-Sama! Vol 1, 2006:6)

Terjemahan:

Sebelumnya para siswa laki-laki bisa berlaku seenaknya dan para siswi hanya bisa mengalah, mana bisa kubiarkan seperti itu! Lalu untuk membalik keadaan aku berusaha sekuat tenaga, akhirnya aku bisa mendapatkan posisi yang pas ini

Data (2) merupakan menunjukkan Misaki sebagai tokoh utama perempuan yang menjadi ketua OSIS di SMA yang $80 \%$ siswanya adalah laki-laki. Hal ini sejalan dengan pandangan feminisme liberal bahwa perempuan dan laki-laki harus mendapatkan kesempatan yang sama dalam memperoleh posisi dalam pekerjaan dan politik.

\section{c. Inferioritas Perempuan}

Feminisme liberal memperjuangkan kesetaraan antara perempuan dan lakilaki. Meskipun terdapat perbedaan antara perempuan dan laki-laki, perempuan bukanlah mahkluk yang inferior (Lorber, 1997:10). Menurut Chaplin (2011:247) Inferior adalah perasaan tidak aman, tidak mantap, tidak tegas merasa tidak berarti sama sekali, dan tidak mampu memenuhi tuntutan-tuntutan hidup. Sejalan dengan pandangan feminisme liberal, komik Kaichō wa Meido-Sama! karya Hiro Fujiwara menggambarkan perempuan yang tegas dan berani. Hal ini ditunjukkan pada gambar (2).

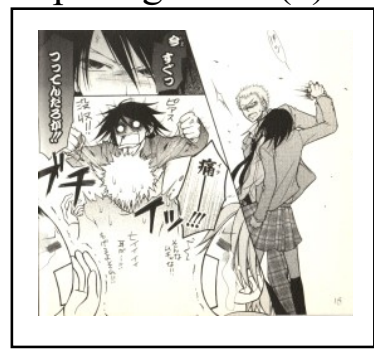

Gambar (2)

(Kaichō wa Meido-Sama! Vol 1, 2006:18)

Gambar (2) adalah gambar yang menunjukkan ketika Misaki mendisiplinkan Shirakawa Naoya, seorang siswa SMA Seika yang kedapatan menggunakan anting. Misaki dengan tegas dan mantap menghalau pukulan Naoya dan mengambil paksa anting yang digunakan Naoya. Tidak ada rasa takut maupun rasa tidak aman yang dirasakan oleh Misaki meskipun yang dihadapinya adalah sekelompok laki-laki. Sebagai ketua OSIS Misaki mendisiplinkan para siswa untuk menaati peraturan dengan tegas meskipun Misaki adalah seorang perempuan. Tokoh Misaki dalam komik Kaichō wa MeidoSama! digambarkan sebagai sosok pemimpin yang tegas dalam mendisiplinkan siswa-siswa di SMA Seika. Hal ini sejalan dengan pemikiran feminisme liberal bahwa meskipun 
terdapat perbedaan antara perempuan dan laki-laki, perempuan bukanlah makhluk inferior yang tidak bisa menjadi pemimpin yang tegas.

d. Diskriminasi terhadap Perempuan

Menurut feminisme liberal, kehidupan sosial modern sangat mendiskriminasi perempuan (Lorber, 1997:10). Perbedaan ekspektasi gender terhadap perempuan dan laki-laki cenderung menimbulkan ketidakadilan terhadap perempuan yang terdiri dari marginalisasi, subbordinasi, stereotip negatif, kekerasan, serta beban kerja (Fakih, 2013:12-23). Dalam komik Kaichō wa Meido-Sama! karya Hiro Fujiwara, diskriminasi terhadap perempuan yang ditunjukkan berupa marginalisasi dan stereotif negatif terhadap perempuan. Marginalisasi atau pemiskinan ekonomi terhadap perempuan ditunjukkan pada data (2)

（2）男はきらいだ、原因ははっきりし

ている。父は借金を残して、蒸発し

たからだ。一番信頼できるはずの男

に裏切られた。おかげで母と私は休

む間もなく働く毎日だ

(会長はメイド様! 第1巻8ページ)

Otoko wa kirai da, gen'in wa hakkiri shiteiru. Chihi wa shakkin wo nokoshite jouhatsu shitakarada. Ichiban shinrai dekiru hazu no otoko ni uragirareta. Okagede haha to watashi wa yasumu ma mo naku hataraku mainichi da

(Kaichō wa Meido-Sama! Vol 1, 2006:8)

Terjemahan:

Aku benci laki-laki, alasannya sangat jelas. Ayahku pergi dari rumah dengan meninggalkan hutang. Kami dihianati oleh laki-laki yang seharusnya menjadi laki-laki yang paling bisa kupercaya. Gara-gara dia ibu dan aku harus bekerja tiap hari tanpa istirahat
Data (2) merupakan narasi yang dijabarkan Misaki mengenai alasannya membenci laki-laki. Ayah Misaki pergi dari rumah dan meninggalkan hutang sehingga Misaki dan Ibunya harus bekerja untuk memenuhi kebutuhan keluarga. Marginalisasi atau pemiskinan ekonomi terhadap perempuan sesungguhnya sudah terjadi dalam ranah rumah tangga (Fakih, 2013:15). Sistem kerja yang cenderung tidak menguntungkan perempuan menyebabkan perempuan menjadi sulit untuk mandiri dan cenderung bergantung kepada suaminya. Di Jepang, upah perempuan hanya $71,3 \%$ dari besar upah laki-laki, yang apabila dibandingkan dengan negara maju lainnya selisih ini sangatlah besar (Kawashima dan Miyake, 2015: 58).

Penggambaran keluarga Ayuzawa dalam komik Kaichō wa Meido-Sama! menunjukkan bahwa keadaan masyarakat khususnya masyarakat Jepang masih mendiskriminasi perempuan. Apabila berpisah dengan suaminya, seorang istri akan mengalami kesulitan. Perempuan seakan dijajah oleh sistem patriarki dan kapitalisme (Sugimoto, 2010:166). Feminisme liberal berusaha untuk menunjukkan bahwa sistem sosisal masyarakat modern masih sangat mendiskriminasi perempuan yang juga ditunjukkan oleh komik Kaichō wa Meido-Sama! karya Hiro Fujiwara.

Diskriminasi terhadap perempuan juga dapat dilihat dari pelabelan negatif terhadap perempuan. Hal ini ditunjukkan pada data (3).

(3) 碓水 : 会長さ、もう少し自覚した

$$
\text { ほうがいいよ }
$$

美咲 : $\cdots$ え ?

碓水 : 強いからって安心して るみたいだけど…あんたも女 のコなんだよ美咲ちやん 
(会長はメイド様！第1巻86 87ページ)

Usui : Kaichō sa, mou sukoshi jikaku shita hou ga ii yo

Misaki : ...e?

Usui : Tsuyoi kara tte anshin shite mitai dakedo... Anta mo onna no ko nandayo Misa-chan

(Kaichō wa Meido-Sama! Vol 1, 2012: 86-

Terjemahan:

Usui : Ketua, seharusnya kau itu lebih peka lagi

Misaki : ...ha?

Usui : Sepertinya kau merasa tenang karena kau kuat... Padahal kau itu juga perempuan lo, Misa-chan

Data (3) menunjukkan bahwa dalam komik Kaichō wa Meido-Sama! masih ada anggapan bahwa perempuan adalah makluk yang lemah. Menolong perempuan bukanlah tindakan yang salah, namun anggapan bahwa perempuan adalah makluk yang lemah cenderung menyebabkan diskriminasi terhadap perempuan. Perempuan akan dibatasi potensinya dan disubbordinasi karena stereotip ini. Stereotip bahwa perempuan adalah makluk yang lemah yang ada di tengah masyarakat merupakan salah satu hal yang diangkat oleh feminisme liberal.

\section{Pengaruh Tokoh Misaki terhadap Tokoh Lainnya}

Pengaruh adalah suatu bentuk efek yang kuat, yang menyebabkan seseorang berpikir atau melakukan suatu tingkah laku tertentu tanpa menggunakan kekerasan atau perintah. Pengaruh feminisme tokoh Misaki terhadap tokoh lainnya dalam komik Kaicho wa MeidoSama! karya Hiro Fujiwara terdiri dari pengaruh positif dan pengaruh negatif. Diantara pengaruh-pengaruh yang ditemukan dalam komik, pengaruh yang dominan ditemukan adalah pengaruh positif. Siswa laki-laki bisa berinteraksi dengan baik dengan siswa perempuan, begitu pula sebaliknya. Siswa laki-laki juga bisa belajar untuk menghormati perempuan sebagai sesama manusia yang setara, sehingga tercipta hubungan sosial yang adil gender. Pengaruh negatif ditunjukkan pada ketergantungan para siswi terhadap pertolongan Misaki. Pengaruh feminisme liberal tokoh Misaki terhadap tokoh lain dalam komik Kaicho wa Meido-Sama! dijabarkan sebagai berikut.

\section{a. Pengaruh Positif}

Menurut feminisme liberal, perempuan harus memiliki hak yang sama dengan laki-laki dari segi pendidikan serta kesempatan kerja (Lorber, 1997:9). Perempuan harus mendapatkan kesempatan yang sama dengan laki-laki dalam menjalankan aktivitasnya yang berkaitan dengan pendidikan. Sebelum Misaki menjadi ketua OSIS di SMA Seika, siswi perempuan cenderung disubbordinasi karena jumlahnya yang sedikit. Namun, hal tersebut mulai berubah sejak Misaki menjadi ketua OSIS. Hal ini ditunjukkan pada data (4).

（4）花園：少し前の星華じや

考えられない状態だよ？！男

子は女子のこと眼中になって

感じだったし。女子は少人数

すぎて環境になじめず静かに

してるだけでしたもんね

…変わつたよね $\cdots$

美咲が生徒会長じやなかつた

ら、こんな思い出も作らなか

つたんだろうなあ

(会長はメイド様! 第18巻122 123ペー 
Hanazono : Sukoshi mae no Seika ja kangaerarenai joutai da yo?! Danshi wa joshi no koto ganchuu ni natte kanji dattashi. Joshi wa shounin zuu sugite kankyou ni najimezu shizuka ni shiteru dake deshita mon ne ... kawatta yo ne .... Misaki ga seitoKaichōu ja nakattara, konna omoide mo tsukuranakattan darou naa

(Kaichō wa Meido-Sama! Vol 18, 2014:122 123)

Terjemahan:

Hanazono: Bukankah ini adalah keadaan yang tak terbayangkan apabila kembali pada Seika yang dulu?! Siswa laki-laki sepertinya sama sekali tidak menghiraukan para siswi. Siswi yang jumlahnya sedikit juga tidak berusaha untuk berbaur dan menjadi pendiam saja. Semuanya telah berubah ya. Jika Misaki tidak menjadi ketua OSIS, kita tidak akan bisa membuat kenangan seperti ini ya

Data (4) adalah data yang menunjukkan percakapan antara Hanazono dan Kaga. Hanazono mengekspresikan keheranannnya tentang perubahan SMA Seika sejak dipimpin oleh Misaki. Hubungan antara siswa dan siswi yang sebelumnya kurang baik kini berubah menjadi bisa berinteraksi dengan baik satu dengan lainnya. Siswa laki-laki menjadi mampu berinteraksi dengan perempuan serta menghormati perempuan sebagai sesama manusia yang setara. Pelanggengan subordinasi, stereotip negatif dan kekerasan gender terhadap perempuan ini secara tidak sadar berasal dari ideologi dan kultur patriarki, yakni ideolgi kelelakian (Fakih,2013:151). Memberikan kesempatan kepada perempuan untuk memperoleh posisi sebagai pemimpin akan meruntuhkan kultur patriarki yang mendiskriminasi perempuan.

\section{b. Pengaruh Negatif}

Selain pengaruh positif, sifat-sifat Misaki yang menunjukkan feminisme liberal juga membawa pengaruh yang negatif. Hal tersebut dapat dilihat dari ketergantungan para siswi terhadap Misaki yang ditunjukkan pada gambar (3).

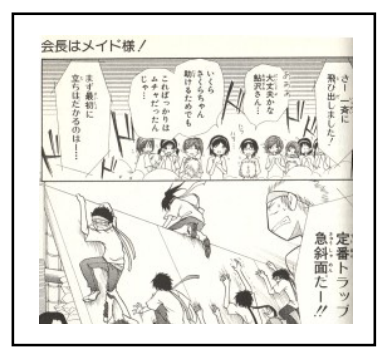

Gambar (3)

(Kaichō wa Meido-Sama!Vol 2, 2007:163)

Gambar (3) menunjukkan para siswi yang menyemangati Misaki yang mengikuti lomba pada festival olah raga. Tokoh Misaki digambarkan sebagai tokoh yang kuat, berani dan tidak inferior, sehingga ia tidak takut meskipun harus berjuang sendirian dalam lomba. Meskipun hal itu merupakan keinginan Misaki untuk menciptakan lingkungan yang lebih nyaman bagi para siswi, hal tersebut cenderung membuat para siswi menjadi ketergantungan terhadap bantuan dari Misaki.

\section{SIMPULAN}

Unsur feminisme dalam komik Kaichō wa Meido Sama! karya Hiro Fujiwara yang paling dominan adalah feminisme liberal. Unsur-unsur feminisme liberal tersebut antara lain: secara biologis perempuan dan laki-laki tidak memiliki perbedaan yang begitu signifikan yang ditunjukkan dengan pencitraan tokoh Misaki yang kuat; perempuan memperoleh kesempatan yang sama dalam posisi politik dan pekerjaan yang ditunjukkan dengan posisi Misaki sebagai Ketua OSIS di SMA Seika; perempuan bukanlah 
makhluk yang inferior yang ditunjukkan dengan tokoh Misaki yang tegas dan berani; serta menunjukkan sistem masyarakat yang masih mendiskriminasi perempuan berupa marginalisasi serta stereotip negatif terhadap perempuan. Sebagai karya sastra yang berbentuk shōjo manga, komik Kaichō wa MeidoSama! menunjukkan gambaran kesetaraan gender yang sejalan dengan pandangan feminisme liberal. Tokoh Misaki sebagai pemimpin yang menunjukkan unsur-unsur pandangan feminisme liberal kemudian mempengaruhi tokoh-tokoh lainnya dalam komik.

Pengaruh feminisme liberal tokoh Misaki terhadap tokoh lain dapat dilihat dari pengaruh positif dan pengaruh negatif. Pengaruh positif terdapat pada perubahan relasi antara siswa perempuan dan laki-laki. Laki-laki mulai bisa berinteraksi dengan perempuan serta menghagai perempuan sebagai mahkluk yang setara. Siswa perempuan juga mulai bisa bersosialisasi dengan siswa laki-laki. Pengaruh negatif dapat dilihat dari ketergantungan siswi perempuan lainnya terhadap pertolongan dari Misaki.

\section{REFERENSI}

Chaplin, James P.2011. Kamus Lengkap Psikologi. Jakarta: Rajagrafindo Persada.

Damayanti, S. (2018). Perempuan dalam Puisi Cinta Shuntaro Tanikawa dan Ws Rendra: sebuah Kajian Sastra Bandingan1. Jurnal Triton Pendidikan, 1(1), 19-26.

Danesi, Marcel. 2011. Pesan, Tanda, dan Makna: Buku Teks Dasar Mengenai Semiotika dan Teori Komunikasi. Yogyakarta: Jalasutra.

Davies, Rojer J. dan Ikeno, Osamu. 2002. The Japanese Mind, Understanding Contemporary Japanese Culture. Singapore: Turtle Publishing.
Fakih, Mansour. 2013. Analisis Gender dan Transformasi Sosial. Yogyakarta: Pustaka Pelajar Offset.

Fujiwara, Hiro. 2006. Kaichō wa MeidoSama! 1. Tokyo: Hakusensha.

Fujiwara, Hiro. 2007a. Kaichō wa Meido-Sama! 2. Tokyo: Hakusensha.

Fujiwara, Hiro. 2007b. Kaichō wa Meido-Sama! 3. Tokyo: Hakusensha.

Fujiwara, Hiro. 2013. Kaichō wa MeidoSama! 18. Tokyo: Hakusensha

Kawashima, Noriko dan Miyake, Eriko. 2015. Shiriizu (Onna, Asu ni Ikiru) 23, Ajia no Naka no Jendā, Tayō na Genjitsu wo Toraekangaeru. Kyōto: Minervashobo

Lorber, Judith. 1997. The Variety of Feminisms and Their Contributions to Gender Equality. Oldenburg: Oldenburg University

Nakamura, Momoko, 2010. Jenda de Yosou Kotoba. Osaka: http://hdl.handle.net/10466/12687 (Diunduh tanggal 10 Januari 2019)

Sisilia, V. P., Dewi, N. M. A. A., \& Damayanti, S. (2016). Pengaruh Pola Asuh Ibu Terhadap Perkembangan Kepribadian Tokoh Hikaru Narumi Dan Hiro Narumi Dalam Manga Piece Karya Ashihara Hinako. Jurnal Humanis, 17(2), 277-285

Sugihastuti dan Suharto. 2010. Kritik Sastra Feminis: Teori dan Aplikasi. Yogyakarta: Pustaka Pelajar

Sugimoto, Yoshio. 2010. An Introduction to Japanese Society. New York: Cambridge University Press. 